\title{
Growth and survival of Bifidobacterium breve and Bifidobacterium longum in various sugar systems with fructooligosaccharide supplementation
}

\author{
Priyanka Parhi ${ }^{1} \cdot$ Keang Peng Song ${ }^{1} \cdot$ Wee Sim $\operatorname{Choo}^{1}$ (])
}

Revised: 16 December 2021 / Accepted: 25 December 2021/Published online: 20 January 2022

(C) The Author(s) 2022

\begin{abstract}
This study aims to investigate the effect of fructooligosaccharide (FOS) $(0.5,1,2,3$, and 4\%) supplementation on the growth and survival of Bifidobacterium breve and Bifidobacterium longum in glucose, fructose, lactose, and sucrose $(2,3$, and $4 \%$ ) systems with 24-h growth and 10-day survival assays at $37^{\circ} \mathrm{C}$. FOS supplementation showed a higher growth-promoting effect on $B$. longum than $B$. breve in various sugar systems. The highest percentage of increase in growth index, $78.5 \%$, was observed with $4 \%$ sucrose supplemented with $0.5 \%$ FOS in B. longum. In comparison, the highest percentage increase in growth index, 5.6 and $6.6 \%$, was observed in the presence of $2 \%$ glucose and $4 \%$ lactose supplemented with $0.5 \%$ FOS in $B$. breve. In survival assay, FOS supplementation $(0.5-4 \%)$ in a $2 \%$ lactose system showed the highest positive effect on the cell viability of B. longum on day-10. As for B. breve, FOS supplementation (1 and 2\%) in the $2 \%$ sucrose system showed the highest positive effect on the cell viability, followed by FOS supplementation $(0.5,3$, and $4 \%)$ in $2 \%$ sucrose and FOS supplementation ( 3 and $4 \%$ ) in $2 \%$ lactose on day-10. This study demonstrated that the efficacy of FOS supplementation was depended on its concentration, sugar system and its concentration, and Bifidobacterium strain.
\end{abstract}

Keywords Glucose · Fructose - Lactose - Sucrose · Prebiotic · Probiotic

Wee Sim Choo

choo.wee.sim@monash.edu

1 School of Science, Monash University Malaysia, 47500 Bandar Sunway, Selangor, Malaysia

\section{Introduction}

Probiotics help normalize perturbed microbiota, organic acid, specially lactis acid and short-chain fatty acids production, regulation of intestinal transit, and competitive exclusion of pathogens. The current definition of probiotics, "live microorganisms that, when administered in adequate amounts, confer a health benefit on the host," was provided by International Scientific Association for Probiotics and Prebiotics (ISAPP) in 2014 (Hill et al. 2014). The natural ability of bifidobacteria to survive in the gastrointestinal tract, resistance mechanisms to bile's salts, and unique fructose-6-phosphate pathway to ferment hexoses make them one of the widely used probiotic bacteria (Shah 2011). Bifidobacterium, a major bacterial group, are classified as gram-positive, non-spore-forming, non-motile, and catalase-negative anaerobes (Shah 2011). They are common inhabitants of the gastrointestinal tract of humans, and vaginal walls account for up to $25 \%$ of the total culturable gut microorganisms in adults. Bifidobacterium helps in plant polysaccharide digestion, human pathogen growth inhibition, resists bile salts, influences hosts' fatty acid metabolism, and shows antipathogenic, anti-inflammatory, and immunomodulation activities (Fanning et al. 2012).

Fructooligosaccharides (FOS) are non-digestible carbohydrates that represent one of the significant classes of bifidogenic oligosaccharides, which are extracted from plants such as yacon root, asparagus, sugar beet, garlic, chicory roots, leeks, onion, Jerusalem artichoke, tomato, and wheat, rye, or barley (Flamm et al. 2001). The fructose units in this mixture of linear fructose polymers and oligomers are linked by $\beta(2-1)$ bonds with terminal glucose (Flamm et al. 2001). Therefore, they are not hydrolyzed by human digestive enzymes and are not absorbed into the 
gastrointestinal tract (Gibson et al. 2004). Prebiotics should not get absorbed by the upper gastrointestinal tract and should resist acid hydrolysis or any modifications by digestive enzymes (Roberfroid 2002). FOS is one of the established prebiotics, defined as "a substrate that is selectively utilized by host microorganisms conferring a health benefit" by the ISAPP (Gibson et al. 2017).

Recently ISAPP redefined synbiotic as "a mixture comprising live microorganisms and substrate(s) selectively utilized by host microorganisms that confers a health benefit on the host" (Swanson et al. 2020). Synbiotics were developed and researched to overcome possible survival difficulties for probiotics during production, storage, and passage through the gastrointestinal tract, significantly improving the probiotic effect (Swanson et al. 2020). However, the supplementation of FOS showed inconsistent effects in various food systems. For examples, FOS supplementation in skim milk improved the viability of $B$. bifidum (Shin et al. 2000) and B. longum (Choi and Shin 2006). Similar positive effect of FOS supplementation was observed on the growth of $B$. lactis in fermented milk (Oliveira et al. 2009), B. longum FTDC 8643 in soymilk (Yeo and Liong 2010), and B. adolescentis and B. catenulatum in milk (Padalino et al. 2012). In addition, Akalın et al. (2004) reported that FOS supplementation in yogurt resulted in better stability of $B$. animalis than B. longum during 21-day storage at $4{ }^{\circ} \mathrm{C}$. Similarly, Celestin et al (2015) reported that FOS supplementation in goat milk yogurts resulted in a higher cell count of L. acidophilus than B. bifidum. On the other hand, no effect of FOS supplementation was reported on the growth of B. infantis in fermented milk (Basholli-Salihu et al. 2013), B. animalis subsp. lactis in fermented cream cheese (Speranza et al. 2018) and B. animalis Bb-12 in soymilk (Battistini et al. 2018). Although there were studies that showed no positive effect of prebiotic supplementation on the viability of probiotics during food fermentation, the use of prebiotics should not be deterred as the positive effect might be exerted in the human large intestine (Amanda and Choo 2018). Since the beneficial effects of prebiotic supplementation on the growth and viability of probiotics in complex food matrices are inconclusive, this study proposed that the effect of prebiotic like FOS on probiotics varies depending on its concentration and the type and concentration of sugar.

Glucose and fructose are monosaccharides that are predominant sugars found in vegetables, fruits, and grains such as rice grain, barley, corn, honey, red grapes, apples, and pomegranates (Liu et al. 2006; White 2014). Lactose, a disaccharide of galactose and glucose with $\beta$-1,4-glycosidic bond, is the predominant sugar in animal milk and animal milk products (Fox 2011; Turroni et al. 2011). Similarly, sucrose, a disaccharide of glucose and fructose with $\alpha-1, \beta-2$-glycosidic bond, is the table sugar derived from sugar beet or sugar cane (Liu et al. 2006; White 2014). Bifidobacterial genomes encode several carbohydrate kinds of transport and modifying enzymes that allow bifidobacteria to utilize and grow on different carbohydrates (Mazé et al. 2007; Parche et al. 2007). B. breve and B. longum are clinically well studied for their probiotical effects on human and animal health and are included in multi-organism probiotics. The potential of $B$. breve and $B$. longum to efficiently digest plant polysaccharides, resistance to low $\mathrm{pH}$ and bile salts, influence host fatty acid metabolism, and show antipathogenic, anti-inflammatory, and immunomodulation activities made them widespread probiotics (Sgorbati et al. 1995; Fanning et al. 2012). To provide insight on food formulations containing stable counts of bifidobacteria, the present study aimed to investigate the effects of FOS supplementation at various concentrations on the growth and survival of Bifidobacterium breve and Bifidobacterium longum in different concentrations of four sugar systems, namely glucose, fructose, sucrose, and lactose.

\section{Materials and methods}

\section{Microbial culture and reactivation of probiotic culture}

Bifidobacterium longum (ATCC BAA-999), and Bifidobacterium breve (ATCC 15700) were purchased directly from American Type Culture Collection (ATCC) Manassas VA, U.S.A. B. longum and B. breve was activated from a glycerol stock. Bifidobacterium agar media was purchased from HiMedia, India. $B$. breve and $B$. longum were maintained in standard Bifidobacterium agar medium at $\mathrm{pH}$ $5.5 \pm 0.2$.

During inoculum preparation, $B$. breve and $B$. longum were grown in Bifidobacterium broth for $18 \mathrm{~h}$ at $37^{\circ} \mathrm{C}$, $120 \mathrm{rpm}$ incubator shaker under anaerobic condition followed by centrifugation at $10,000 \times g$ for $10 \mathrm{~min}$ at $\stackrel{4}{\mathrm{C}}$.

\section{Preparation of modified Bifidobacterium broth for $\boldsymbol{B}$. longum and $B$. breve}

Modified Bifidobacterium broth $(1000 \mathrm{~mL})$ with $\mathrm{pH}$ $6.5 \pm 0.2$ was prepared using peptone special $(22.2 \mathrm{~g})$, $\mathrm{NaCl}(4.8 \mathrm{~g})$, and L-cysteine hydrochloride monohydrate $(0.5 \mathrm{~g})$ with prebiotics and sugars. Four different sugars (fructose, sucrose, glucose, and lactose) at different concentrations $(1,2,3$, and 4\%) with FOS supplementation at different concentrations $(0.5,1,2,3$, and $4 \%)$ were used for growth and survival assays. Agar powder, phosphate-buffered saline (PBS) tablets, anaerogens, peptone special, 
sodium chloride $(\mathrm{NaCl})$, and L-cysteine hydrochloride monohydrate were purchased from Oxoid, UK. Glucose, fructose, sucrose, lactose, and gram staining kit were purchased from Sigma-Aldrich, USA. Fructooligosaccharide (FOS) was obtained from Fiatec Biosystems Sdn. Bhd, Malaysia, with a degree of polymerization between 3 and 8.

\section{Growth curve assay}

Modified Bifidobacterium broth $(250 \mu \mathrm{L})$ was dispensed in a 96-well plate in an anaerobic chamber, and the plate was then incubated and measured simultaneously inside a TECAN Spark ${ }^{\circledR} 10$ M microplate reader (TECAN, Grödig, Austria) at $37{ }^{\circ} \mathrm{C}$ for $24 \mathrm{~h}$. Microbial growth was monitored by measuring the absorbance at OD 600 every $60 \mathrm{~min}$ intervals, with $15 \mathrm{~s}$ auto-shaking at $1440 \mathrm{rpm}$ before each measurement. Growth Index (\%) was calculated using the equation according to Bevilacqua et al. (2016), modified by Parhi et al. (2021a):

Growth Index $(\%)=\left\{\frac{\mathrm{OD}_{\mathrm{MAX}}-\mathrm{OD}_{\mathrm{NC}}}{\mathrm{OD}_{\mathrm{PC}}}\right\} \times 100$

where $\mathrm{OD}_{\mathrm{MAX}}$ was the maximum absorbance attained, $\mathrm{OD}_{\mathrm{NC}}$ was the absorbance of negative control (Modified Bifidobacterium broth without any sugar and FOS), and $\mathrm{OD}_{\mathrm{PC}}$ was the absorbance of positive control (Modified Bifidobacterium broth with $4 \%$ glucose).

\section{Enumeration of bacteria and $\mathrm{pH}$ measurement}

The number of viable cells in culture per $\mathrm{mL}$ was determined by spread plating $0.1 \mathrm{~mL}$ of serially diluted cultures on Bifidobacterium agar media and incubated at $37{ }^{\circ} \mathrm{C}$ for $48 \mathrm{~h}$ under anaerobic conditions. Enumeration was expressed as $\log \mathrm{CFU} / \mathrm{mL}$. In addition, the $\mathrm{pH}$ of the samples was measured by pH-meter F-71 (LAQUA, U.S.A) after $24 \mathrm{~h}$.

\section{Survival assay}

Modified Bifidobacterium broth $(20 \mathrm{~mL})$ was dispensed in Schott bottles and inoculated at $5 \%$ w/v with $B$. long$u m$ and $B$. breve. The cultures were incubated at $37{ }^{\circ} \mathrm{C}$ under anaerobic conditions for 10 days. The cell viability (\%) and $\mathrm{pH}(\mathrm{pH}-m e t e r$ F-71 (LAQUA, USA) were measured at 2-days intervals. The percentage cell viability of probiotics is calculated using the equation below (Parhi et al. 2021b):

Cell Viability $(\%)=C F U m L_{\text {Day }-T}^{-1} / C F U m L_{\text {Day }-0}^{-1} \times 100 \%$ where $C F U m L^{-1}{ }_{\text {Day }-T}$ was the viable cell count at the day of analysis and $C F U m L^{-1}{ }_{\text {Day-0 }}$ was the initial viable cell count.

\section{Statistical analysis}

All the assays were conducted in independent triplicates. The results were statically analyzed using one-way analysis of variance (ANOVA) and Tukey's test for post-hoc analysis. Statistical significance was determined at $p<0.05$ using Statistical Package for the Social Sciences (SPSS) Version 23 from IBM Corporation (New York, U.S.A.).

\section{Results and discussion}

\section{Growth index of B. breve and B. longum in different sugar systems with FOS supplementation}

Tables 1 and 2 show the growth index (\%) of $B$. breve and $B$. longum grown in modified Bifidobacterium medium with 2, 3, 4\% glucose, fructose, sucrose, and lactose supplemented with $0.5,1,2,3,4 \%$ FOS. The growth index of $B$. longum significantly increased when the concentration of FOS, as the sole carbohydrate source, was increased from 0.5 to $4 \%$, suggesting a dose-dependent effect of FOS on the growth (Table 1). Although a similar dose-dependent effect was observed with 0.5 and $1 \%$ FOS supplementation as a sole carbohydrate source of $B$. breve, further increase $(2,3,4 \%)$ showed a significant decrease in growth index, which indicates partial inhibition (Table 2). The growth index of $B$. longum was $76.7 \%$ with $3 \%$ FOS while $B$. breve grew well with a growth index of $85 \%$ on $1 \%$ FOS as the sole carbohydrate source (Tables 1 and 2). The growth index $>75 \%$ stands for growth kinetics similar to that reported for the optimal conditions; growth index in the range of $25-75 \%$ underlines a partial inhibition; growth index $<25 \%$ stands for potent inhibition of the microorganism (Bevilacqua et al. 2016). These results suggest that FOS as the sole carbohydrate source supported the growth of Bifidobacterium. But the required concentration of FOS was different, and the growth kinetics varied according to the strain. B. breve ATCC 15698, 15700, and B. longum ATCC 15708 were reported to grow in 2\% FOS as a sole carbohydrate source in de Man Rogosa Sharpe (MRS) agar (Kaplan and Hutkins 2000). B. longum ATCC 15707 and $B$. breve 15700 were reported to grow in 5\% FOS as sole carbohydrate source (Kajiwara et al. 2002), where else $B$. breve MB 252 and $B$. longum PRO 2 were able to grow in $1 \%$ FOS as sole carbohydrate source (Rossi et al. 2005). The ability of bifidobacterial to grow on FOS might be 
Table 1 Growth Index (\%) of B. longum grown in modified Bifidobacterium broth containing 2, 3, and 4\% of glucose, fructose, sucrose, and lactose supplemented with $0.5,1,2,3$, and $4 \%$ of fructooligosaccharide during 24 -h growth at $37{ }^{\circ} \mathrm{C}$

\begin{tabular}{|c|c|c|c|c|c|c|c|}
\hline & & \multicolumn{6}{|c|}{ Fructooligosaccharide } \\
\hline & & $0 \%$ & $0.5 \%$ & $1 \%$ & $2 \%$ & $3 \%$ & $4 \%$ \\
\hline Sugar & $0 \%$ & $40.06 \pm 0.82^{\mathrm{Aa}}$ & $58.16 \pm 0.58^{\mathrm{Ab}}$ & $67.45 \pm 0.45^{\mathrm{Ac}}$ & $74.86 \pm 0.79^{\mathrm{Ae}}$ & $76.72 \pm 0.29^{\mathrm{Af}}$ & $73.01 \pm 0.57^{\mathrm{Ad}}$ \\
\hline \multirow[t]{3}{*}{ Glucose } & $2 \%$ & $90.93 \pm 0.36^{\mathrm{Hb}}$ & $96.60 \pm 0.19^{\mathrm{Ed}}$ & $95.92 \pm 0.40^{\mathrm{Fd}}$ & $92.51 \pm 0.60^{\mathrm{BCc}}$ & $89.45 \pm 0.59^{\mathrm{Cb}}$ & $80.12 \pm 1.047^{\mathrm{C}}$ \\
\hline & $3 \%$ & $92.41 \pm 0.69^{\mathrm{HIb}}$ & $94.56 \pm 0.10^{\mathrm{Dc}}$ & $94.87 \pm 0.43^{\mathrm{Ec}}$ & $92.97 \pm 0.61^{\mathrm{BCb}}$ & $90.11 \pm 0.47^{\mathrm{Ca}}$ & $89.87 \pm 0.54^{\mathrm{Ea}}$ \\
\hline & $4 \%$ & $100.00 \pm 0.43^{\mathrm{Jc}}$ & $98.85 \pm 0.51^{\mathrm{FGb}}$ & $96.51 \pm 0.29^{\mathrm{FGa}}$ & $98.27 \pm 0.49^{\mathrm{Fb}}$ & $98.67 \pm 0.77^{\mathrm{Eb}}$ & $97.03 \pm 0.40^{\mathrm{Hb}}$ \\
\hline \multirow[t]{3}{*}{ Fructose } & $2 \%$ & $80.54 \pm 0.53^{\mathrm{Eb}}$ & $98.31 \pm 0.63^{\mathrm{Fd}}$ & $98.08 \pm 0.49^{\mathrm{GHd}}$ & $95.53 \pm 0.55^{\mathrm{DEc}}$ & $81.74 \pm 0.56^{\mathrm{Bb}}$ & $77.82 \pm 1.01^{\mathrm{Ba}}$ \\
\hline & $3 \%$ & $84.51 \pm 0.58^{\mathrm{Fa}}$ & $96.85 \pm 0.40^{\mathrm{Ee}}$ & $97.67 \pm 0.85^{\mathrm{Gf}}$ & $94.93 \pm 0.39^{\mathrm{Dd}}$ & $90.81 \pm 0.65^{\mathrm{BCc}}$ & $88.60 \pm 0.08^{\mathrm{Ab}}$ \\
\hline & $4 \%$ & $94.11 \pm 0.38^{\mathrm{Ie}}$ & $90.30 \pm 0.67^{\mathrm{Cd}}$ & $86.92 \pm 0.57^{\mathrm{Bc}}$ & $84.63 \pm 0.69^{\mathrm{Bb}}$ & $81.85 \pm 0.67^{\mathrm{Ba}}$ & $84.71 \pm 0.66^{\mathrm{Db}}$ \\
\hline \multirow[t]{3}{*}{ Sucrose } & $2 \%$ & $74.19 \pm 0.77^{\mathrm{Da}}$ & $90.06 \pm 0.64^{\mathrm{Cb}}$ & $98.44 \pm 1.23^{\mathrm{He}}$ & $98.22 \pm 0.25^{\mathrm{Fe}}$ & $94.85 \pm 0.61^{\mathrm{Dd}}$ & $92.71 \pm 0.51^{\mathrm{Gc}}$ \\
\hline & $3 \%$ & $63.76 \pm 0.76^{\mathrm{Ca}}$ & $87.08 \pm 0.52^{\mathrm{Bb}}$ & $87.71 \pm 0.66^{\mathrm{Cb}}$ & $96.74 \pm 0.56^{\mathrm{EFe}}$ & $95.17 \pm 0.28^{\mathrm{Dd}}$ & $91.37 \pm 0.33^{\mathrm{Fc}}$ \\
\hline & $4 \%$ & $54.96 \pm 0.50^{\mathrm{Ba}}$ & $98.09 \pm 0.91^{\mathrm{Ed}}$ & $96.77 \pm 0.35^{\mathrm{Db}}$ & $96.01 \pm 0.61^{\mathrm{Fe}}$ & $94.56 \pm 0.56^{\mathrm{Dc}}$ & $94.99 \pm 0.84^{\mathrm{FGc}}$ \\
\hline \multirow[t]{3}{*}{ Lactose } & $2 \%$ & $84.12 \pm 0.82^{\mathrm{Fa}}$ & $95.93 \pm 0.38^{\mathrm{DEc}}$ & $97.61 \pm 0.72^{\mathrm{Ge}}$ & $91.86 \pm 1.04^{\mathrm{Bb}}$ & $99.60 \pm 0.64^{\mathrm{EFb}}$ & $96.77 \pm 0.64^{\mathrm{Hd}}$ \\
\hline & $3 \%$ & $87.09 \pm 0.79^{\mathrm{Ga}}$ & $99.14 \pm 0.62^{\mathrm{Gf}}$ & $97.41 \pm 0.42^{\mathrm{Gd}}$ & $92.57 \pm 0.11^{\mathrm{BCc}}$ & $98.04 \pm 0.99^{\text {Eef }}$ & $91.81 \pm 0.36^{\mathrm{FGt}}$ \\
\hline & $4 \%$ & $92.82 \pm 0.77^{\mathrm{HIa}}$ & $108.02 \pm 0.74^{\mathrm{Hc}}$ & $109.51 \pm 0.75^{\text {Id }}$ & $109.87 \pm 0.32^{\mathrm{Gd}}$ & $109.13 \pm 0.22^{\mathrm{Gd}}$ & $106.72 \pm 0.33^{\mathrm{Ib}}$ \\
\hline
\end{tabular}

Values are presented as means \pm standard deviations $(n=3)$. ${ }^{\text {abc }}$ Difference in lower case letters within a row indicates significant difference at $p<0.05{ }^{\mathrm{ABC}}$ Difference in upper case letters within a column indicates significant difference at $p<0.05$. NC: Negative control (no sugar and FOS)

Table 2 Growth Index (\%) of B. breve grown in modified Bifidobacterium broth containing 2, 3, and 4\% of glucose, fructose, sucrose, and lactose supplemented with $0.5,1,2,3$, and $4 \%$ of fructooligosaccharide during 24 -h growth at $37{ }^{\circ} \mathrm{C}$

\begin{tabular}{|c|c|c|c|c|c|c|c|}
\hline & & \multicolumn{6}{|c|}{ Fructooligosaccharide } \\
\hline & & $0 \%$ & $0.5 \%$ & $1 \%$ & $2 \%$ & $3 \%$ & $4 \%$ \\
\hline Sugar & $0 \%$ & $36.33 \pm 0.60^{\mathrm{Aa}}$ & $66.61 \pm 1.53^{\mathrm{Bc}}$ & $85.02 \pm 1.48^{\mathrm{De}}$ & $76.83 \pm 0.46^{\mathrm{Dd}}$ & $65.69 \pm 0.72^{\mathrm{Ec}}$ & $55.03 \pm 0.78^{\mathrm{Db}}$ \\
\hline \multirow[t]{3}{*}{ Glucose } & $2 \%$ & $92.01 \pm 0.41^{\mathrm{Be}}$ & $97.20 \pm 0.33^{\mathrm{Gf}}$ & $55.48 \pm 0.40^{\mathrm{Bd}}$ & $51.54 \pm 0.47^{\mathrm{Bc}}$ & $44.07 \pm 0.79^{\mathrm{Bb}}$ & $40.39 \pm 0.18^{\mathrm{Ba}}$ \\
\hline & $3 \%$ & $99.21 \pm 0.21^{\mathrm{Ce}}$ & $88.60 \pm 0.56^{\mathrm{Ed}}$ & $79.21 \pm 0.57^{\mathrm{Cc}}$ & $78.80 \pm 0.61^{\mathrm{DEc}}$ & $39.04 \pm 0.75^{\mathrm{Ab}}$ & $26.74 \pm 0.71^{\mathrm{Aa}}$ \\
\hline & $4 \%$ & $100.00 \pm 0.46^{\mathrm{Ce}}$ & $46.33 \pm 0.47^{\mathrm{Ac}}$ & $40.62 \pm 0.91^{\mathrm{Aa}}$ & $44.57 \pm 0.59^{\mathrm{Ab}}$ & $48.94 \pm 0.31^{\mathrm{Cd}}$ & $47.38 \pm 0.53^{\mathrm{Ccd}}$ \\
\hline \multirow[t]{3}{*}{ Fructose } & $2 \%$ & $117.39 \pm 0.77^{\mathrm{Ge}}$ & $94.51 \pm 0.36^{\mathrm{Fd}}$ & $85.23 \pm 0.81^{\mathrm{Db}}$ & $88.20 \pm 0.80^{\mathrm{Gc}}$ & $86.58 \pm 0.49^{\mathrm{Jb}} \mathrm{c}$ & $74.04 \pm 0.83^{\mathrm{Ha}}$ \\
\hline & $3 \%$ & $117.90 \pm 1.22^{\mathrm{Gf}}$ & $80.43 \pm 0.10^{\mathrm{Cd}}$ & $83.02 \pm 0.79^{\mathrm{De}}$ & $76.97 \pm 0.89^{\mathrm{DEc}}$ & $56.90 \pm 0.94^{\mathrm{Db}}$ & $48.94 \pm 0.70^{\mathrm{Ca}}$ \\
\hline & $4 \%$ & $94.01 \pm 0.19^{\mathrm{Bd}}$ & $85.26 \pm 0.70^{\mathrm{Dc}}$ & $82.70 \pm 0.56^{\text {Dab }}$ & $81.70 \pm 1.21^{\mathrm{Fa}}$ & $81.86 \pm 0.64^{\mathrm{Iab}}$ & $83.90 \pm 0.91^{\mathrm{Jbc}}$ \\
\hline \multirow[t]{3}{*}{ Sucrose } & $2 \%$ & $108.83 \pm 0.83^{\mathrm{Ef}}$ & $101.92 \pm 0.72^{\mathrm{He}}$ & $89.89 \pm 0.72^{\mathrm{Ed}}$ & $77.28 \pm 0.18^{\mathrm{DEc}}$ & $71.90 \pm 1.09^{\mathrm{Fb}}$ & $62.97 \pm 0.76^{\mathrm{Fa}}$ \\
\hline & $3 \%$ & $104.96 \pm 0.64^{\mathrm{Df}}$ & $98.09 \pm 1.82^{\mathrm{Ge}}$ & $94.68 \pm 1.06^{\mathrm{Fd}}$ & $90.99 \pm 0.52^{\mathrm{Hc}}$ & $78.06 \pm 0.34^{\mathrm{Hb}}$ & $55.76 \pm 0.78^{\mathrm{Da}}$ \\
\hline & $4 \%$ & $104.57 \pm 1.73^{\mathrm{De}}$ & $87.85 \pm 0.66^{\mathrm{Ed}}$ & $77.31 \pm 1.13^{\mathrm{Cc}}$ & $67.89 \pm 1.35^{\mathrm{Cb}}$ & $66.12 \pm 0.51^{\text {Eab }}$ & $64.49 \pm 0.27^{\mathrm{FGa}}$ \\
\hline \multirow[t]{3}{*}{ Lactose } & $2 \%$ & $101.20 \pm 0.30^{\mathrm{Cde}}$ & $103.23 \pm 0.79^{\mathrm{He}}$ & $100.89 \pm 0.84^{\mathrm{Gd}}$ & $97.63 \pm 1.38^{\mathrm{Jc}}$ & $74.63 \pm 0.72^{\mathrm{Gb}}$ & $66.50 \pm 0.31^{\mathrm{Ga}}$ \\
\hline & $3 \%$ & $113.54 \pm 0.41^{\mathrm{Fe}}$ & $106.35 \pm 0.85^{\mathrm{Id}}$ & $105.19 \pm 0.94^{\mathrm{Hd}}$ & $95.09 \pm 0.49^{\mathrm{Ic}}$ & $84.59 \pm 0.30^{\mathrm{Jb}}$ & $79.67 \pm 0.94^{\mathrm{Ia}}$ \\
\hline & $4 \%$ & $110.23 \pm 0.88^{\mathrm{Ee}}$ & $117.53 \pm 0.42^{\mathrm{Jf}}$ & $105.09 \pm 0.49^{\mathrm{Hd}}$ & $79.33 \pm 0.74^{\mathrm{EFc}}$ & $76.89 \pm 0.61^{\mathrm{Hb}}$ & $58.05 \pm 0.97^{\mathrm{Ea}}$ \\
\hline
\end{tabular}

Values are presented as means \pm standard deviations $(n=3) .{ }^{\text {abc }}$ Difference in lower case letters within a row indicates significant difference at $p<0.05{ }^{\mathrm{ABC}}$ Difference in upper case letters within a column indicates significant difference at $p<0.05$. NC: Negative control (no sugar and FOS)

attributed to the degree of polymerization of FOS ( 3 to 8), as short-chain FOS were fermented more quickly by bifidobacteria than long-chain oligosaccharides (Perrin et al. 2001; Rossi et al. 2005). Similar positive effects of shortchain FOS on the growth of bifidobacteria were reported previously. The degree of polymerization varies from 3 to 4 (Kaplan and Hutkins 2000), 3 to 8 (Perrin et al. 2001), 3-10 (Rossi et al. 2005), and 3-7 (Padalino et al. 2012). Bifidobacterial $\beta$-fructofuranosidase specifically cleaves $\beta$ $(2-1)$ bonds releasing fructose moieties in the growth 
medium and providing an additional carbon source for the microorganism (Ryan et al. 2005). However, the $\beta$ fructofuranosidase activity depends on the degree of polymerization and strain of bifidobacteria (Hopkins et al. 1998; Ryan et al. 2005).

The percentage increase was determined by comparing the growth index of the FOS supplemented sugar system with the growth index of the non-supplemented respective sugar system. The highest percentage of increase in growth index, $78.5 \%$ of B. longum, was observed with $4 \%$ sucrose supplemented with $0.5 \%$ FOS (Table 1). The supplementation of $0.5-4 \%$ FOS resulted in the percentage increase in growth index of $21.5-78.3 \%$ (Table 1 ) of B. longum along with a significant increase in cell density to approximately 9.36-10.47 $\log$ CFU/mL (Table 3) in the presence of 2, 3, $4 \%$ sucrose, suggesting a growth-promoting effect of FOS (Table 1). B. longum also showed a significant increase in cell density to approximately 9.36-10.47 $\log \mathrm{CFU} / \mathrm{mL}$ (Table 3) correlating with a significant decrease in $\mathrm{pH}$ (4.98-6.00) in media containing both sucrose and FOS compared to non-supplemented media (Table S1, supplementary data). Yeo and Liong (2010) reported positive effects of FOS supplementation on the growth of B. longum FTDC 8643 in soymilk. Sucrose is the predominant sugar in soymilk (Turroni et al. 2011). The FOS supplementation significantly improved the growth index of B. longum in the presence of sucrose (Table 1) because B. longum comprises multiple sugar transport systems and an additional pathway known as a fructose-6-phosphate shunt or 'bifid' shunt (De Vries and Stouthamer 1967), and the ability to produce carbohydrate modifying enzymes. According to Kullin et al. (2006), the $\csc A$ ( $\beta$-fructofuranosidase) and $\operatorname{scr} P$ (sucrose phosphorylase) gene clusters of B. longum NCIMB 702259 function mainly in the metabolism of intracellular sucrose generated from the breakdown of more complex carbohydrates. The scrP gene was up-regulated in the presence of sucrose relative to glucose (Kullin et al. 2006). Henceforth, the growth-promoting effect of FOS in the presence of sucrose may be due to $B$. longum utilizing sucrose and FOS simultaneously.

In the lactose system, B. longum showed the highest percentage of increase in growth index of $18.4 \%$ in $4 \%$ lactose with $2 \%$ FOS supplementation (Table 1). A significant increase in the cell density to approximately 8.29-10.46 $\log$ CFU/mL (Table 3) was observed in a medium containing lactose with FOS supplementation compared to the non-supplemented lactose system. $B$. breve showed the significant highest increase of $6.6 \%$ in the growth index in $4 \%$ lactose supplemented with $0.5 \%$ FOS, suggesting a growth-promoting effect at a low concentration of FOS in the lactose system (Table 2). Similarly, the supplementation of FOS was the most effective in enhancing the growth rate of both B. bifidum Bf-1 and Bf-6 in skim milk (Shin et al. 2000) and induced a higher growth rate in B. adolescentis and B. catenulatum in milk (Padalino et al. 2012). FOS supplementation also showed the most increase in the growth-promoting activity for $B$. breve 3022 and B. longum 3128 in skim milk (Choi and Shin

Table 3 Viable count (log CFU/mL) of B. longum grown in modified Bifidobacterium broth containing 2, 3, and 4\% of glucose, fructose, sucrose, and lactose supplemented with $0.5,1,2,3$ and $4 \%$ of fructooligosaccharide during 24 -h growth at $37{ }^{\circ} \mathrm{C}$

\begin{tabular}{|c|c|c|c|c|c|c|c|}
\hline & & \multicolumn{6}{|c|}{ Fructooligosaccharide } \\
\hline & & $0 \%$ & $0.5 \%$ & $1 \%$ & $2 \%$ & $3 \%$ & $4 \%$ \\
\hline Sugar & $0 \%$ & $6.03 \pm 0.51^{\mathrm{Aa}}$ & $7.97 \pm 0.01^{\mathrm{Ab}}$ & $8.20 \pm 0.01^{\mathrm{Ab}}$ & $8.21 \pm 0.01^{\mathrm{Ab}}$ & $8.28 \pm 0.00^{\mathrm{Bb}}$ & $8.21 \pm 0.01^{\mathrm{Bb}}$ \\
\hline \multirow[t]{3}{*}{ Glucose } & $2 \%$ & $8.20 \pm 0.03^{\mathrm{Ca}}$ & $9.19 \pm 0.04^{\mathrm{BCb}}$ & $10.13 \pm 0.04^{\mathrm{Dc}}$ & $10.32 \pm 0.02^{\mathrm{Ed}}$ & $9.15 \pm 0.02^{\mathrm{Db}}$ & $8.20 \pm 0.05^{\mathrm{Ba}}$ \\
\hline & $3 \%$ & $8.24 \pm 0.04^{\mathrm{Ca}}$ & $9.27 \pm 0.02^{\mathrm{CDc}}$ & $9.09 \pm 0.04^{\mathrm{Bb}}$ & $9.28 \pm 0.03^{\mathrm{Cc}}$ & $9.16 \pm 0.01^{\mathrm{Dbc}}$ & $8.22 \pm 0.03^{\mathrm{Ba}}$ \\
\hline & $4 \%$ & $8.06 \pm 0.08^{\mathrm{Ca}}$ & $10.31 \pm 0.04^{\mathrm{Gd}}$ & $10.12 \pm 0.03^{\mathrm{Dc}}$ & $9.27 \pm 0.08^{\mathrm{Cb}}$ & $8.20 \pm 0.06^{\mathrm{Ba}}$ & $8.18 \pm 0.01^{\mathrm{Ba}}$ \\
\hline \multirow[t]{3}{*}{ Fructose } & $2 \%$ & $8.15 \pm 0.03^{\mathrm{Ca}}$ & $9.09 \pm 0.11^{\mathrm{Bb}}$ & $10.12 \pm 0.08^{\mathrm{Dc}}$ & $10.18 \pm 0.03^{\mathrm{Dc}}$ & $8.01 \pm 0.04^{\mathrm{Aa}}$ & $8.00 \pm 0.02^{\mathrm{Aa}}$ \\
\hline & $3 \%$ & $8.13 \pm 0.04^{\mathrm{Ca}}$ & $9.12 \pm 0.02^{\mathrm{Bc}}$ & $9.04 \pm 0.08^{\mathrm{Bbc}}$ & $9.15 \pm 0.06^{\mathrm{Bc}}$ & $8.95 \pm 0.06^{\mathrm{Cbc}}$ & $8.90 \pm 0.08^{\mathrm{Cb}}$ \\
\hline & $4 \%$ & $8.14 \pm 0.02^{\mathrm{Cb}}$ & $10.05 \pm 0.01^{\mathrm{Fe}}$ & $9.02 \pm 0.05^{\mathrm{Bc}}$ & $8.30 \pm 0.01^{\mathrm{Ac}}$ & $7.97 \pm 0.03^{\mathrm{Aa}}$ & $8.00 \pm 0.02^{\mathrm{Aa}}$ \\
\hline \multirow[t]{3}{*}{ Sucrose } & $2 \%$ & $7.05 \pm 0.02^{\mathrm{Ba}}$ & $9.34 \pm 0.03^{\mathrm{DEc}}$ & $10.47 \pm 0.02^{\mathrm{Ee}}$ & $10.33 \pm 0.00^{\mathrm{Ed}}$ & $9.34 \pm 0.02^{\mathrm{Ec}}$ & $8.30 \pm 0.03^{\mathrm{Bb}}$ \\
\hline & $3 \%$ & $7.00 \pm 0.02^{\mathrm{Ba}}$ & $9.47 \pm 0.03^{\mathrm{Ec}}$ & $9.36 \pm 0.01^{\mathrm{Cb}}$ & $10.33 \pm 0.02^{\mathrm{Ed}}$ & $10.43 \pm 0.01^{\mathrm{Ge}}$ & $9.41 \pm 0.01^{\mathrm{Dbc}}$ \\
\hline & $4 \%$ & $7.62 \pm 0.03^{\mathrm{Ba}}$ & $10.36 \pm 0.04^{\mathrm{Gcd}}$ & $10.39 \pm 0.01^{\mathrm{Ed}}$ & $10.36 \pm 0.01^{\mathrm{Ecd}}$ & $10.26 \pm 0.01^{\mathrm{Fb}}$ & $10.30 \pm 0.02^{\mathrm{Ebc}}$ \\
\hline \multirow[t]{3}{*}{ Lactose } & $2 \%$ & $8.31 \pm 0.03^{\mathrm{Ca}}$ & $9.33 \pm 0.02^{\mathrm{DEb}}$ & $10.35 \pm 0.00^{\mathrm{Ec}}$ & $10.37 \pm 0.02^{\mathrm{Ec}}$ & $9.33 \pm 0.03^{\mathrm{Eb}}$ & $8.29 \pm 0.02^{\mathrm{Ba}}$ \\
\hline & $3 \%$ & $8.28 \pm 0.03^{\mathrm{Ca}}$ & $9.31 \pm 0.01^{\mathrm{Db}}$ & $9.33 \pm 0.02^{\mathrm{Cb}}$ & $10.35 \pm 0.01^{\mathrm{Ec}}$ & $10.31 \pm 0.01^{\mathrm{Fc}}$ & $9.27 \pm 0.03^{\mathrm{Db}}$ \\
\hline & $4 \%$ & $8.34 \pm 0.04^{\mathrm{Ca}}$ & $10.36 \pm 0.01^{\mathrm{Gcd}}$ & $10.38 \pm 0.01^{\mathrm{Ed}}$ & $10.36 \pm 0.01^{\mathrm{Ec}}$ & $10.32 \pm 0.02^{\mathrm{Fb}}$ & $10.46 \pm 0.00^{\mathrm{Ee}}$ \\
\hline
\end{tabular}

Values are presented as means \pm standard deviations $(n=3)$. ${ }^{\text {abc }}$ Difference in lower case letters within a row indicates significant difference at $p<0.05{ }^{\mathrm{ABC}}$ Difference in upper case letters within a column indicates significant difference at $p<0.05$. NC: Negative control (no sugar and FOS) 
2006). Lactose is the predominant sugar in milk-based products. Most of the predominant bifidobacterial species in infants' intestines, B. longum, B. breve, and B. bifidum, produce galacto- $N$-biose/lacto- $N$-biose I phosphorylase responsible for lacto- $N$-biose degradation (Turroni et al. 2011; Xiao et al. 2010). In addition, Parche et al (2006) reported that putative glucose transporter gene $g l c P$ in $B$. longum NCC2705 is repressed by lactose when grown in a medium containing both lactose and glucose. Therefore, $B$. longum and $B$. breve might be using both lactose and FOS simultaneously, resulting in a positive effect of FOS in the lactose system.

In glucose and fructose systems, 1.7-6.2\% and $4.8-22.1 \%$ increase in growth index was observed in 2 and $3 \%$ glucose and fructose with $0.5-2 \%$ and $0.5-4 \%$ FOS supplementation, respectively, suggesting a positive effect of FOS supplementation on the growth of B. longum in lower concentrations of glucose and fructose (Table 1). Interestingly, $B$. breve showed a $5.6 \%$ increase in growth index in the presence of $2 \%$ glucose supplemented with $0.5 \%$ FOS (Table 2). At the same time, other combinations showed partial inhibition of $B$. longum and $B$. breve (Tables 1 and 2). For example, Parche et al. (2007) reported the sugar transport system of B. longum NCC 2705, which included ABC, PEP-PTS, major intrinsic protein family (MIP), Major facilitator superfamily (MFS), and glycoside-pentoside-hexuronide cation symporter family (GPH). These multiple sugar transport systems in $B$. longum give it the ability to uptake a wide range of carbohydrates, including polymers such as FOS, which can be the reason behind the positive effect of FOS supplementation on the growth index of $B$. longum in all four sugars (Table 1). However, the operon in B. breve UCC2003, which can break down FOS, was activated when grown in sucrose but repressed when grown in glucose, fructose, or combinations of glucose-sucrose, fructose-sucrose (Ryan et al. 2005). This might be occurring here, resulting in significantly lower growth index values $(p<0.05)$ of $B$. breve grown in several media containing glucose, fructose, and lactose with FOS supplementation as compared to the positive control of glucose without supplementation (Table 2).

B. longum comprises multiple sugar transport systems (De Vries and Stouthamer 1967) and can produce carbohydrate modifying enzymes. According to Pokusaeva et al (2011), the Bifidobacterium genome reflects the metabolic adaptation to a complex carbohydrate-rich gastrointestinal tract environment as it encodes a large number of predicted carbohydrate-modifying enzymes. Therefore, B. longum can utilize different carbohydrates resulting in a positive effect on the growth index with FOS supplementation. Similarly, a positive effect on the $\log \mathrm{CFU} / \mathrm{mL}$ of $B$. longum was observed, resulting in a $2-3 \log$ increase in log
$\mathrm{CFU} / \mathrm{mL}$ in the sucrose system and $1-2 \log$ increase in log $\mathrm{CFU} / \mathrm{mL}$ in glucose, fructose, lactose systems with FOS supplementation compared to respective sugar systems without FOS supplementation (Table 3). Nevertheless, $B$. breve showed no $\log \mathrm{CFU} / \mathrm{mL}$ increase with FOS supplementation in sugar systems (Table 4). The sharp decrease in $\mathrm{pH}$ in media might explain the difference in $\log \mathrm{CFU} / \mathrm{mL}$ of $B$. breve except for the lactose system (Table S2, supplementary data). This is most likely due to the growth index being calculated as the total sum of all the OD taken every hour, while $\log \mathrm{CFU} / \mathrm{mL}$ was calculated by taking CFU initially and at the end of $24 \mathrm{~h}$. However, B. breve and $B$. longum entered the initial death phase due to depletion of carbon source, media acidification, and accumulation of organic acids, resulting in a decrease in CFU at the end. Nevertheless, microbial growth and survival during the production and storage of fermented foods are subjected to several abiotic stresses such as acidification of media, nutritional availability, and accumulation of byproducts and dead cells in ferment media strongly depend on the cells to adapt.

\section{Survival of B. longum and B. breve in different sugar systems with FOS supplementation}

The survival assay focused on the effects of FOS on the death kinetics of $B$. breve and $B$. longum at $37{ }^{\circ} \mathrm{C}$. As expected, the cell viability of $B$. longum and $B$. breve increased until day- 2 of the assay. However, a decrease in cell viability of $B$. longum and $B$. breve was observed with cell viability of $68.6-73.4 \%$ and $64.7-72.8 \%$ on day-6, suggesting both the microorganism showed prolonged viability in sugar systems with and without FOS supplementation, respectively (data not shown). The changes in survival and $\mathrm{pH}$ of $B$. longum and $B$. breve in various sugar systems with FOS supplementation on day- 8 and day-10 are presented in Figs. 1, 2, and Figs. S1, S2 (supplementary data). These 2 days were selected to evaluate the difference between the survival of $B$. breve and $B$. longum in sugar systems with and without FOS supplementation at the death phase. The decline in cell viability after day-2 and no change in $\mathrm{pH}$ after day- 6 suggested media saturation and acidification (data not shown). In the presence of $2 \%$ sugar systems without FOS supplementation, the cell viability of B. longum and B. breve was between $39-46 \%$ and $0 \%$ on day- 8 , respectively. However, $0 \%$ cell viability was observed for both B. longum and B. breve in 2\% sugar systems without FOS supplementation (Figs. 1a and 2a). Similarly, Akalin et al. (2004) reported a decrease in the cell viability and $\mathrm{pH}$ of $B$. longum after seven days of refrigerated storage, concluding that the low $\mathrm{pH}$ was the critical factor in the viability of bifidobacterial cells. Acetic acid and lactic acid, byproducts of bifidobacteria, are 
Table 4 Viable count $(\log$ CFU/mL) of B. breve grown in modified Bifidobacterium broth containing 2, 3, and $4 \%$ of glucose, fructose, sucrose, and lactose supplemented with $0.5,1,2,3$ and $4 \%$ of fructooligosaccharide during 24 -h growth at $37{ }^{\circ} \mathrm{C}$

\begin{tabular}{|c|c|c|c|c|c|c|c|}
\hline & & \multicolumn{6}{|c|}{ Fructooligosaccharide } \\
\hline & & $0 \%$ & $0.5 \%$ & $1 \%$ & $2 \%$ & $3 \%$ & $4 \%$ \\
\hline Sugar & $0 \%$ & $6.19 \pm 0.00^{\mathrm{Aa}}$ & $7.21 \pm 0.03^{\mathrm{Ab}}$ & $7.46 \pm 0.45^{\mathrm{Ab}}$ & $7.08 \pm 0.01^{\mathrm{Ab}}$ & $7.07 \pm 0.00^{\mathrm{Ab}}$ & $7.11 \pm 0.12^{\mathrm{Ab}}$ \\
\hline \multirow[t]{3}{*}{ Glucose } & $2 \%$ & $8.12 \pm 0.04^{\mathrm{BCa}}$ & $8.13 \pm 0.04^{\mathrm{Ba}}$ & $8.32 \pm 0.00^{\mathrm{BCb}}$ & $8.29 \pm 0.02^{\mathrm{EFb}}$ & $8.32 \pm 0.00^{\mathrm{CDb}}$ & $8.29 \pm 0.01^{\mathrm{Cb}}$ \\
\hline & $3 \%$ & $8.20 \pm 0.02^{\mathrm{BCa}}$ & $8.29 \pm 0.05^{\mathrm{BCab}}$ & $8.29 \pm 0.00^{\mathrm{BCbc}}$ & $8.27 \pm 0.01^{\mathrm{EFbc}}$ & $8.32 \pm 0.01^{\mathrm{CDc}}$ & $8.29 \pm 0.01^{\mathrm{Cbc}}$ \\
\hline & $4 \%$ & $8.44 \pm 0.00^{\mathrm{Dd}}$ & $8.32 \pm 0.01^{\mathrm{BCc}}$ & $8.27 \pm 0.01^{\mathrm{BC}} \mathrm{b}$ & $8.30 \pm 0.00^{\mathrm{EFbc}}$ & $8.16 \pm 0.02^{\mathrm{Ca}}$ & $8.28 \pm 0.00^{\mathrm{Bb}}$ \\
\hline \multirow[t]{3}{*}{ Fructose } & $2 \%$ & $7.99 \pm 0.01^{\mathrm{Bab}}$ & $7.97 \pm 0.04^{\mathrm{Ba}}$ & $8.05 \pm 0.02 \mathrm{~B}^{\mathrm{Cabc}}$ & $8.01 \pm 0.07^{\mathrm{Babc}}$ & $8.08 \pm 0.01^{\mathrm{Bbc}}$ & $8.11 \pm 0.01^{\mathrm{Bc}}$ \\
\hline & $3 \%$ & $8.00 \pm 0.04^{\mathrm{Ba}}$ & $8.00 \pm 0.08^{\mathrm{Ba}}$ & $7.96 \pm 0.02^{\mathrm{Ba}}$ & $8.07 \pm 0.01^{\mathrm{BCa}}$ & $8.08 \pm 0.02^{\mathrm{Ba}}$ & $8.09 \pm 0.01^{\mathrm{Ba}}$ \\
\hline & $4 \%$ & $8.15 \pm 0.03^{\mathrm{BCc}}$ & $8.07 \pm 0.02^{\mathrm{Bab}}$ & $8.02 \pm 0.02^{\mathrm{BCa}}$ & $8.12 \pm 0.02^{\mathrm{BCDbc}}$ & $8.06 \pm 0.01^{\mathrm{Bab}}$ & $8.09 \pm 0.03^{\mathrm{Bab}}$ \\
\hline \multirow[t]{3}{*}{ Sucrose } & $2 \%$ & $8.03 \pm 0.04^{\mathrm{Bab}}$ & $8.16 \pm 0.03^{\mathrm{BCbc}}$ & $8.17 \pm 0.02^{\mathrm{BCc}}$ & $8.21 \pm 0.07^{\mathrm{DEc}}$ & $8.21 \pm 0.02^{\mathrm{Cc}}$ & $8.02 \pm 0.03^{\mathrm{Ba}}$ \\
\hline & $3 \%$ & $8.17 \pm 0.21^{\mathrm{BCa}}$ & $8.61 \pm 0.47^{\mathrm{Ca}}$ & $8.10 \pm 0.02^{\mathrm{BCa}}$ & $8.18 \pm 0.08^{\mathrm{CDEa}}$ & $8.28 \pm 0.03^{\mathrm{Da}}$ & $8.14 \pm 0.11^{\mathrm{Ca}}$ \\
\hline & $4 \%$ & $8.19 \pm 0.01^{\mathrm{BCb}}$ & $8.30 \pm 0.00^{\mathrm{BCc}}$ & $8.10 \pm 0.03^{\mathrm{BCa}}$ & $8.32 \pm 0.01^{\mathrm{EFc}}$ & $8.30 \pm 0.01^{\mathrm{CDc}}$ & $8.34 \pm 0.01^{\mathrm{Cc}}$ \\
\hline \multirow[t]{3}{*}{ Lactose } & $2 \%$ & $8.30 \pm 0.00^{\mathrm{CDa}}$ & $8.36 \pm 0.01^{\mathrm{BCb}}$ & $8.35 \pm 0.03^{\mathrm{BCb}}$ & $8.35 \pm 0.01^{\mathrm{Fb}}$ & $8.30 \pm 0.00^{\mathrm{CDa}}$ & $8.35 \pm 0.02^{\mathrm{Cb}}$ \\
\hline & $3 \%$ & $8.28 \pm 0.02^{\mathrm{CDa}}$ & $8.33 \pm 0.01^{\mathrm{BCbc}}$ & $8.34 \pm 0.00^{\mathrm{Cc}}$ & $8.30 \pm 0.00^{\mathrm{EFab}}$ & $8.32 \pm 0.02^{\text {CDabc }}$ & $8.34 \pm 0.01^{\mathrm{Cbc}}$ \\
\hline & $4 \%$ & $8.34 \pm 0.01^{\mathrm{CDb}}$ & $8.38 \pm 0.01^{\mathrm{BCc}}$ & $8.36 \pm 0.00^{\mathrm{Cbc}}$ & $8.30 \pm 0.00^{\mathrm{EFa}}$ & $8.34 \pm 0.01^{\mathrm{Eb}}$ & $8.36 \pm 0.02^{\mathrm{Cbc}}$ \\
\hline
\end{tabular}

Values are presented as means \pm standard deviations $(n=3)$. ${ }^{\text {abc }}$ Difference in lower case letters within a row indicates significant difference at $p<0.05{ }^{\mathrm{ABC}}$ Difference in upper case letters within column indicates a significant difference at $p<0.05$. NC: Negative control (no sugar and FOS)

known as environmental stress that may inhibit the growth of microorganisms by entering the cell in its non-dissociated form and then dissociating within the cell, which causes acidification of the cytoplasm, collapsing of the proton motive force, and inhibition of the enzyme reactions, resulting in the inhibition of nutrient transport (Guan and Liu 2020). Although $\mathrm{pH}$ was below 4.0 (Figs. S1 and $\mathrm{S} 2$, supplementary data), both B. longum and $B$. breve showed $39-44 \%$ cell viability in 3 and 4\% sugar systems without FOS supplementation. This could be due to the ability of bifidobacteria to produce exopolysaccharides (EPS) under stressful conditions, thereby providing tolerance against acidic $\mathrm{pH}$, contributing to cell protection and survival (Alp and Aslim 2010; Fanning et al. 2012). Audy et al (2010) suggested that EPS production by B. longum BB79 and B. longum CRC002 were induced by lactose, fructose, and glucose. B. breve UCC2003 and B. breve DSM20213 were reported to produce exopolysaccharides, thus increasing stress tolerance against low $\mathrm{pH}$ (Alp and Aslim 2010; Fanning et al. 2012).

The $50 \%$ cell viability of B. longum and B. breve in $2 \%$ sugar systems with FOS supplementation on day-8 suggests FOS supplementation resulted in slower death kinetic (Fig. 1a and 2a). B. longum showed the highest cell viability of $43-44 \%$ in $2 \%$ lactose with FOS supplementation on day-10. However, B. breve showed the highest cell viability of $42 \%$ in the $2 \%$ sucrose system with 1 and $2 \%$ FOS supplementation followed by $2 \%$ sucrose system with $0.5,3,4 \%$ FOS supplementation, and $2 \%$ lactose with 3 and $4 \%$ FOS supplementation on day-10 (Fig. 2a). These results suggest the positive effect of FOS supplementation on the cell viability of $B$. longum in all sugar systems till day-10. However, the cell viability of $B$. breve was only observed in $2 \%$ sucrose with $0.5-4 \%$ FOS supplementation, and 2\% lactose with 3 and $4 \%$ FOS supplementation on day-10 (Fig. 2a). Nevertheless, the difference in survival of B. longum and $B$. breve suggests the diverse nature of Bifidobacterium to utilize simple and complex carbohydrates, which also can vary between strains and species (Parche et al. 2007).

In higher concentrations, 3 and $4 \%$ sugar systems, the FOS supplementation positively influenced cell viability of B. longum, resulting in $39-44 \%$ cell viability on day-10 (Fig. 1b and c). Similarly, B. breve showed 39-42\% cell viability in 3 and $4 \%$ sugar systems with FOS supplementation on day-10 (Fig. $2 b$ and 2c). These results are consistent with previous reports on the ability of FOS to stimulate the viability of Bifidobacterium in different mediums. For example, FOS supplementation in skim milk was effective in increasing the viability of B. bifidum Bf-1 and Bf-6 after four weeks at $4{ }^{\circ} \mathrm{C}$ (Shin et al. 2000), and viability of $B$. longum was significantly higher with FOS supplementation in skim milk at $4{ }^{\circ} \mathrm{C}$ for four weeks storage (Choi and Shin 2006). In addition, Akalin et al. (2004) reported that $B$. longum maintained viability above $10^{6} \mathrm{CFU} / \mathrm{g}$ in yoghurt containing FOS for up to 21 days at $4{ }^{\circ} \mathrm{C}$. 

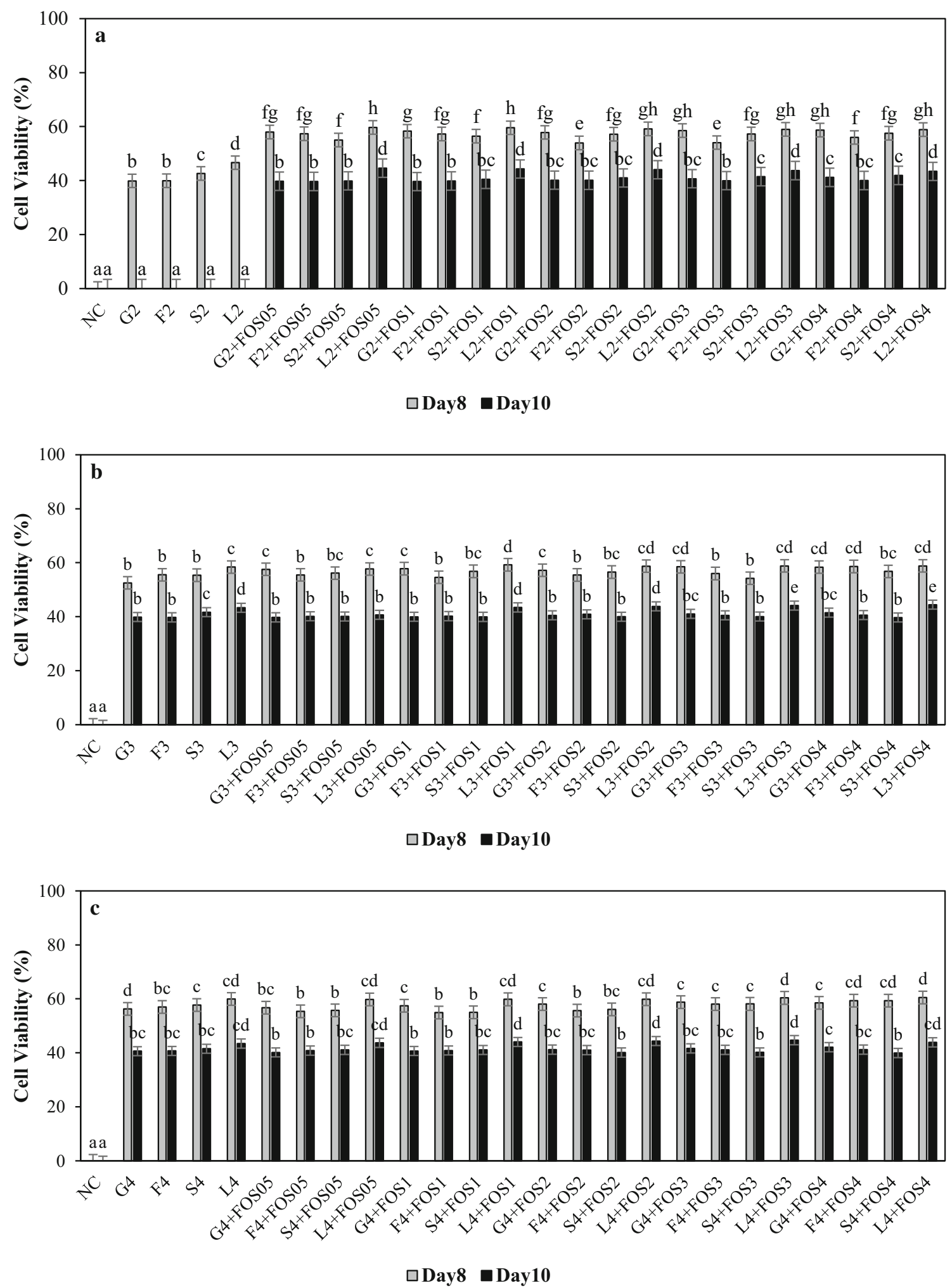

Fig. 1 Cell viability (\%) of B. longum grown in modified Bifidobacterium broth containing a $2 \%$ glucose $(\mathrm{G} 2)$, fructose (F2), sucrose (S2), lactose (L2), b $3 \%$ glucose (G3), fructose (F3), sucrose (S3), lactose (L3), and (c) $4 \%$ glucose (G4), fructose (F4), sucrose (S4), lactose (L4) with $0.5 \%$ (FOS05), $1 \%$ (FOS1), $2 \%$ (FOS2), 3\% (FOS3) and 4\% (FOS4) fructooligosaccharide on 8th and 10th day. ${ }^{\text {abc }}$ Difference in lower case letters indicates significant differences between different treatments within a same day at $p<0.05$. $\mathrm{NC}=$ negative control (no sugar and FOS) 

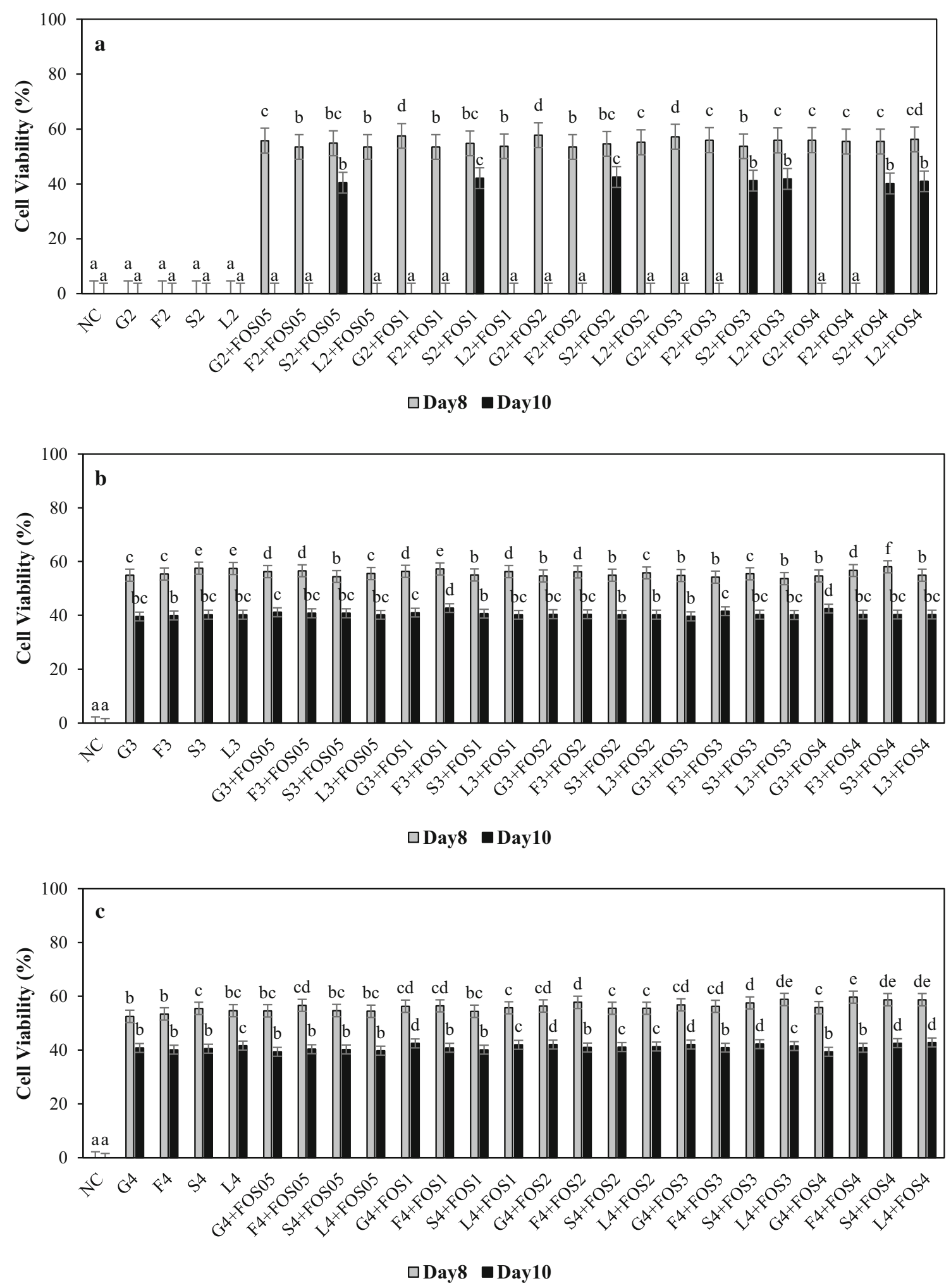

Fig. 2 Cell viability (\%) of B. breve grown in modified Bifidobacterium broth containing a) $2 \%$ glucose (G2), fructose (F2), sucrose (S2), lactose (L2), b $3 \%$ glucose $(\mathrm{G} 3)$, fructose $(\mathrm{F} 3)$, sucrose $(\mathrm{S} 3)$, lactose (L3), and c $4 \%$ glucose (G4), fructose (F4), sucrose (S4), lactose (L4) with $0.5 \%$ (FOS05), $1 \%$ (FOS1), $2 \%$ (FOS2), 3\% (FOS3) and 4\% (FOS4) fructooligosaccharide on 8th and 10th day. abc Difference in lower case letters indicates significant differences between different treatments within a same day at $p<0.05$. $\mathrm{NC}=$ negative control (no sugar and FOS) 


\section{Conclusion}

The present study shows that FOS supplementation significantly increased the growth index of B. longum in most sugar systems, with few exceptions. However, only $2 \%$ glucose and $4 \%$ lactose supplemented with $0.5 \%$ FOS supplementation showed a significant increase in the growth index of $B$. breve. Based on the highest percentage increase in growth index, sucrose was the most suitable sugar for FOS supplementation for B. longum, whereas lactose was the most suitable sugar for FOS supplementation for $B$. breve. Furthermore, in the survival assay, FOS supplementation in $2 \%$ sugar systems effectively influenced the cell viability and slowed the death phase of $B$. longum and $B$. breve. The highest cell viability of B. longum was observed in $2 \%$ lactose with FOS supplementation. On the other hand, the highest cell viability of $B$. breve was observed in $2 \%$ sucrose with FOS supplementation. Thus, the growth and survival of $B$. longum and $B$. breve were improved and prolonged with FOS supplementation, but the effect was depended on the concentration and type of sugar system and FOS concentration. This study demonstrated that the use of sugar systems without the complexity of a food matrix provided valuable information to understand the effect of FOS supplementation on the growth and survival of B. longum and B. breve. However, as there are other components in a food matrix that may influence the growth and survival of $B$. longum and $B$. breve, the results in this study cannot be directly applied to a food matrix. Nevertheless, these results provide insights into developing efficient and improved synbiotic products containing bifidobacteria with FOS supplementation.

Supplementary Information The online version contains supplementary material available at https://doi.org/10.1007/s13197022-05361-z.

Acknowledgements The authors acknowledge School of Science, Monash University Malaysia for the support in this work.

Authors' contributions PP-original draft, writing, performed the analysis and data collection. KPS - supervision, editing and writing. WSC - conceptualization, project management, supervision, editing and writing.

Funding Open Access funding enabled and organized by CAUL and its Member Institutions. School of Science, Monash University Malaysia.

Availability of data and material Not applicable.

Code availability Not applicable.

\section{Declarations}

Conflicts of interest The authors declare that they have no conflict of interest.

Ethics approval Not applicable.

Consent to participate Not applicable.

Consent for publication Not applicable.

Open Access This article is licensed under a Creative Commons Attribution 4.0 International License, which permits use, sharing, adaptation, distribution and reproduction in any medium or format, as long as you give appropriate credit to the original author(s) and the source, provide a link to the Creative Commons licence, and indicate if changes were made. The images or other third party material in this article are included in the article's Creative Commons licence, unless indicated otherwise in a credit line to the material. If material is not included in the article's Creative Commons licence and your intended use is not permitted by statutory regulation or exceeds the permitted use, you will need to obtain permission directly from the copyright holder. To view a copy of this licence, visit http://creativecommons. org/licenses/by/4.0/.

\section{References}

Akalın AS, Fenderya S, Akbulut N (2004) Viability and activity of Bifidobacteria in yoghurt containing fructooligosaccharide during refrigerated storage. Int J Food Sci Technol 39(6):613-621. https://doi.org/10.1111/j.1365-2621.2004.00829.x

Alp G, Aslim B (2010) Relationship between the resistance to bile salts and low $\mathrm{pH}$ with exopolysaccharide (EPS) production of Bifidobacterium spp. isolated from infants' feces and breast milk. Anaerobe 16(2):101-105. https://doi.org/10.1016/j.anae robe.2009.06.006

Amanda E, Choo WS (2018) Effect of refrigerated storage on the physicochemical characteristics and viability of Lactobacillus plantarum in fermented watermelon juice with or without supplementation with inulin or fructooligosaccharide. J Food Process Preserv 42(12):13831. https://doi.org/10.1111/jfpp. 13831

Audy J, Labrie S, Roy D, LaPointe G (2010) Sugar source modulates exopolysaccharide biosynthesis in Bifidobacterium longum subsp. longum CRC 002. Microbiology 156(3):653-664. https://doi.org/10.1099/mic.0.033720-0

Basholli-Salihu M, Mueller M, Unger FM, Viernstein H (2013) The use of cellobiose and fructooligosaccharide on growth and stability of Bifidobacterium infantis in fermented milk. Food Sci Nutr 4(12):1301. https://doi.org/10.4236/fns.2013.412167

Battistini C, Gullón B, Ichimura ES, Gomes AMP, Ribeiro EP, Kunigk L, Moreira JUV, Jurkiewicz C (2018) Development and characterization of an innovative synbiotic fermented beverage based on vegetable soybean. Braz J Microbiol 49(2):303-309. https://doi.org/10.1016/j.bjm.2017,08(00),pp.6

Bevilacqua A, Sinigaglia M, Speranza B, Altieri C (2016) Effect of prebiotic compounds on the growth and survival of bifidobacteria in a laboratory medium. Adv J Food Sci Technol 11(12):770-774. https://doi.org/10.19026/ajfst.11.2790

Celestin S, Thorat SS, Desale RJ, Chavan UD (2015) Effect of milk supplementation with fructooligosaccharides and inulin on viable counts of probiotic bacteria in goat and cow milk yoghurts. IOSR J Environ Sci Toxicol Food Technol 9(7):6-12. https://doi.org/10.9790/2402-09710612 
Choi NY, Shin HS (2006) Effect of oligosaccharides and inulin on the growth and viability of bifidobacteria in skim milk. Food Sci Biotechnol 15(4):543-548

De Vries W, Stouthamer AH (1967) Pathway of glucose fermentation in relation to the taxonomy of bifidobacteria. $\mathrm{J}$ Bacteriol 93(2):574-576. https://doi.org/10.1128/jb.93.2.574-576,1967

Fanning S, Hall LJ, Cronin M, Zomer A, MacSharry J, Goulding D, Motherway MOC, Shanahan F, Nally K, Dougan G, van Sinderen D (2012) Bifidobacterial surface-exopolysaccharide facilitates commensal-host interaction through immune modulation and pathogen protection. Proc Natl Acad Sci 109(6):2108-2113. https://doi.org/10.1073/pnas.1115621109

Flamm G, Glinsmann W, Kritchevsky D, Prosky L, Roberfroid M (2001) Inulin and oligofructose as dietary fiber: a review of the evidence. Crit Rev Food Sci Nutr 41(5):353-362. https://doi.org/ 10.1080/20014091091841

Fox PF (2011) Bovine milk. In: Fuquay JW, Fox PF, McSweeney PLH (eds) Encyclopaedia of dairy sciences, 2nd edn. Academic Press, San Diego, pp 478-483

Gibson GR, Probert HM, Van Loo J, Rastall RA, Roberfroid MB (2004) Dietary modulation of the human colonic microbiota: updating the concept of prebiotics. Nutr Res Rev 17(2):259-275. https://doi.org/10.1079/nrr200479

Gibson GR, Hutkins R, Sanders ME, Prescott SL, Reimer RA, Salminen SJ, Scott K, Stanton C, Swanson KS, Cani PD, Verbeke K (2017) Expert consensus document: The International Scientific Association for Probiotics and Prebiotics (ISAPP) consensus statement on the definition and scope of prebiotics. Nat Rev Gastroenterol Hepatol 14(8):491-502. https://doi.org/ 10.1038/nrgastro.2017.75

Guan N, Liu L (2020) Microbial response to acid stress: mechanisms and applications. Appl Microbiol Biotechnol 104(1):51-65. https://doi.org/10.1007/s00253-019-10226-1

Hill C, Guarner F, Reid G, Gibson GR, Merenstein DJ, Pot B, Morelli L, Canani RB, Flint HJ, Salminen S (2014) Expert consensus document: The International Scientific Association for Probiotics and Prebiotics consensus statement on the scope and appropriate use of the term probiotic. Nat Rev Gastroenterol Hepatol 11(8):506-514. https://doi.org/10.1038/nrgastro.2014.66

Hopkins M, Cummings J, Macfarlane G (1998) Inter-species differences in maximum specific growth rates and cell yields of bifidobacteria cultured on oligosaccharides and other simple carbohydrate sources. J Appl Microbiol 85(2):381-386. https:// doi.org/10.1046/j.1365-2672.1998.00524.x

Kajiwara S, Gandhi H, Ustunol Z (2002) Effect of honey on the growth of and acid production by human intestinal Bifidobacterium spp.: an in vitro comparison with commercial oligosaccharides and inulin. J Food Prot 65(1):214-218. https://doi.org/ 10.4315/0362-028x-65.1.214

Kaplan H, Hutkins RW (2000) Fermentation of fructooligosaccharides by lactic acid bacteria and bifidobacteria. Appl Environ Microbiol 66(6):2682-2684. https://doi.org/10.1128/aem.66.6. 2682-2684.2000

Kullin B, Abratt VR, Reid SJ (2006) A functional analysis of the Bifidobacterium longum cscA and scrP genes in sucrose utilization. Appl Microbiol Biotechnol 72(5):975-981. https:// doi.org/10.1007/s00253-006-0358-x

Liu Y, Ying Y, Yu H, Fu X (2006) Comparison of the HPLC method and FT-NIR analysis for quantification of glucose, fructose, and sucrose in intact apple fruits. J Agric Food Chem 54(8):2810-2815. https://doi.org/10.1021/jf052889e

Mazé A, O'Connell-Motherway M, Fitzgerald GF, Deutscher J, Van Sinderen D (2007) Identification and characterization of a fructose phosphotransferase system in Bifidobacterium breve UCC2003. Appl Environ Microbiol 73(2):545-553. https://doi. org/10.1128/AEM.01496-06
Oliveira RP, Florence AC, Silva RC, Perego P, Converti A, Gioielli LA, Oliveira MN (2009) Effect of different prebiotics on the fermentation kinetics, probiotic survival and fatty acids profiles in nonfat symbiotic fermented milk. Int $\mathrm{J}$ Food Microbiol 128:467-472. https://doi.org/10.1016/j.ijfoodmicro.2008.10.012

Padalino M, Perez-Conesa D, López-Nicolás R, Frontela-Saseta C, Ros-Berruezo G (2012) Effect of fructooligosaccharides and galactooligosaccharides on the folate production of some folateproducing bacteria in media cultures or milk. Int Dairy $\mathbf{J}$ 27(1-2):27-33. https://doi.org/10.1016/j.idairyj.2012.06.006

Parche S, Beleut M, Rezzonico E, Jacobs D, Arigoni F, Titgemeyer F, Jankovic I (2006) Lactose-over-glucose preference in Bifidobacterium longum NCC2705:glcP, encoding a glucose transporter, is subject to lactose repression. J Bacteriol 188(4):1260-1265. https://doi.org/10.1128/JB.188.4.1260-1265.2006

Parche S, Amon J, Jankovic I, Rezzonico E, Beleut M, Barutçu H, Schendel I, Eddy MP, Burkovski A, Arigoni F, Titgemeyer F (2007) Sugar transport systems of Bifidobacterium longum NCC2705. J Mol Microbiol Biotechnol 12(1-2):9-19. https:// doi.org/10.1159/000096455

Parhi P, Song KP, Choo WS (2021b) Viability, storage stabilityand in vitro gastrointestinal tolerance of Lactiplantibacillus plantarum Grown in model sugar systems with inulin and fructooligosaccharide supplementation. Fermentation 7(4):259. https://doi.org/10.3390/fermentation7040259

Parhi P, Song KP, Choo WS (2021a) Effect of inulin and fructooligosaccharide supplementation on the growth and survival of Lactobacillus casei in model sugar systems. J Food Process Preserv 45(3):15228. https://doi.org/10.n1111/jfpp. 15228

Perrin S, Warchol M, Grill JP, Schneider F (2001) Fermentations of fructo-oligosaccharides and their components by Bifidobacterium infantis ATCC 15697 on batch culture in semi-synthetic medium. J Appl Microbiol 90:859-865. https://doi.org/10.1046/ j.1365-2672.2001.01317.x

Pokusaeva K, Fitzgerald GF, Van Sinderen D (2011) Carbohydrate metabolism in bifidobacteria. Genes Nutr 6(3):285. https://doi. org/10.1007/s12263-010-0206-6

Roberfroid M (2002) Functional food concept and its application to prebiotics. Dig Liver Dis 34:S105-S110. https://doi.org/10.1016/ s1590-8658(02)80176-1

Rossi M, Corradini C, Amaretti A, Nicolini M, Pompei A, Zanoni S, Matteuzzi D (2005) Fermentation of fructooligosaccharides and inulin by bifidobacteria: a comparative study of pure and fecal cultures. Appl Environ Microbiol 71:6150-6158. https://doi.org/ 10.1128/aem.71.10.61506158.2005

Ryan SM, Fitzgerald G, van Sinderen D (2005) Transcriptional regulation and characterization of a novel $\beta$-fructofuranosidaseencoding gene from Bifidobacterium breve UCC2003. Appl Environ Microbiol 71(7):3475-3482. https://doi.org/10.1128/ aem.71.7.3475-3482,2005

Sgorbati B, Biavati B, Palenzona D (1995) The genus Bifidobacterium. In: Wood BJB, Holzapfel WH (eds) The genera of lactic acid bacteria. Springer, Boston, MA, pp 279-306

Shah NP (2011) Bacteria, beneficiall Bifidobacterium spp.: morphology and physiology. In: Fuquay JW (ed) Encyclopaedia of dairy sciences, 2nd edn. Academic Press, San Diego, pp 381-387

Shin HS, Lee JH, Ustunol PJJ, Z, (2000) Growth and viability of commercial Bifidobacterium spp in skim milk containing oligosaccharides and inulin. J Food Sci 65(5):884-887. https:// doi.org/10.1111/j.1365-2621.2000.tb13605.x

Speranza B, Campaniello D, Monacis N, Bevilacqua A, Sinigaglia M, Corbo MR (2018) Functional cream cheese supplemented with bifidobacterium animalis subsp. lactis DSM 10140 and Lactobacillus reuteri DSM 20016 and prebiotics. Food Microbiol 72:16-22. https://doi.org/10.1016/j.fm.2017.11.001 
Swanson KS, Gibson GR, Hutkins R, Reimer RA, Reid G, Verbeke K, Scott KP, Holscher HD, Azad MB, Delzenne NM, Sanders ME (2020) The International Scientific Association for Probiotics and Prebiotics (ISAPP) consensus statement on the definition and scope of synbiotics. Nat Rev Gastroenterol Hepatol 17:687-701. https://doi.org/10.1038/s41575-020-0344-2

Turroni F, Foroni E, Serafini F, Viappiani A, Montanini B, Bottacini F, Ferrarini A, Bacchini PL, Rota C, Delledonne M, Ottonello S (2011) Ability of Bifidobacterium breve to grow on different types of milk: exploring the metabolism of milk through genome analysis. Appl Environ Microbiol 77(20):7408-7417. https://doi. org/10.1128/AEM.05336-11

White JS (2014) Sucrose, HFCS, and fructose: history, manufacture, composition, applications, and production. In: James MR (ed)
Fructose, high fructose corn syrup, sucrose and health. Humana Press, New York, NY, pp 13-33

Xiao JZ, Takahashi S, Nishimoto M, Odamaki T, Yaeshima T, Iwatsuki K, Kitaoka M (2010) Distribution of in vitro fermentation ability of lacto-N-biose I, a major building block of human milk oligosaccharides, in bifidobacterial strains. Appl Environ Microbiol 76(1):54-59. https://doi.org/10.1128/aem.01683-09

Yeo SK, Liong MT (2010) Effect of prebiotics on viability and growth characteristics of probiotics in soymilk. J Sci Food Agric 90(2):267-275. https://doi.org/10.1002/jsfa.3808

Publisher's Note Springer Nature remains neutral with regard to jurisdictional claims in published maps and institutional affiliations. 